\title{
Treatment options for T-cell lymphomas: a single-center study
}

\author{
Elena E. Lepik ${ }^{1}$, Andrey V. Kozlov $^{1}$, Evgenia S. Borzenkova ${ }^{1}$, Yury R. Zalyalov ${ }^{1}$, Kirill V. Lepik ${ }^{1}$, Elena V. Kondakova ${ }^{1}$, \\ Vadim V. Baykov ${ }^{1}$, Ivan S. Moiseev ${ }^{1}$, Tatiana V. Schneider ${ }^{2}$, Natalia B. Mikhaylovaa ${ }^{1}$, Boris V. Afanasyev ${ }^{1}$ \\ ${ }^{1}$ Raisa Gorbacheva Memorial Research Institute of Pediatric Oncology, Hematology and Transplantation, Pavlov University, \\ St. Petersburg, Russia \\ ${ }^{2}$ Leningrad Regional Clinical Hospital, St. Petersburg, Russia
}

Dr. Elena E. Lepik, Clinical Hematologist, Oncology

Department, Raisa Gorbacheva Memorial Research Institute of Pediatric Oncology, Hematology and Transplantation,

Pavlov University, L. Tolstoy St. 6-8, 197022, St. Petersburg,

Russia
Phone: +7 (905) 2268922

E-mail: ee.dav@mail.ru

Citation: Lepik EE, Kozlov AV, Borzenkova ES et al. Treatment options for T-cell lymphomas: a single-center study. Cell Ther Transplant 2020; 9(1): 28-37.

\section{Summary}

T-cell lymphomas (TCL) comprise a group of aggressive non-Hodgkin lymphomas, which do not have successful treatment standards. Almost 70\% of patients undergoing first-line therapy develop a relapse or refractory $(r / r)$ disease. A number of novel therapy approaches are aimed for improvement of outcomes in patients with $\mathrm{r} / \mathrm{r}$ TCL. This report summarizes clinical experience of Pavlov Medical University in the treatment of T cell lymphomas. We analyzed data of 47 patients with TCL treated from 2005 to 2019. Of them, 44 had r/r TCL, and 3 patients were in complete response after first line therapy. The median age was 45 years (range 1-72 years). These were predominantly patients with peripheral T-cell lymphomas not otherwise specified (TCL-NOS, 41\%). 26 patients ( $55 \%$ of total) had a primary chemoresistant disease, while the remaining 18 patients (38\% of total) had a relapse after initial treatment.

Our center has implemented new treatment options for r/r TCL, i.e., anti CD30 monoclonal antibody brentuximab, ALK inhibitor crizotinib, immunotherapy with checkpoint inhibitors nivolumab, and hematopoietic stem cell transplantation (HSCT). A total of 24 patients underwent: high-dose chemotherapy with autologous HSCT (auto-HSCT) was performed in 16 cases, 13 patients were subjected to allogeneic HSCT (allo-HSCT), including 5 relapsed patients after auto-HSCT. At the time of analysis, 35 patients remained alive. The median follow-up of surviving patients was 35 months (6-122 mo). The median overall survival (OS) was not reached, 5-year survival rate was $81 \%$, and 8-year survival rate was $78 \%$. Complete remission (CR) at the last follow-up was diagnosed in 22 patients; partial response (PR), in 4 cases, and progression of the disease (PD) was revealed in 21 patients. Among factors significantly associated with adverse prognosis were lower ECOG performance status and B-symptoms at the time of diagnosis $(p=0.06)$. The patients who underwent HSCT showed significantly better disease status at the moment of last follow up: $17 / 19$ (89\%) were in CR, versus 5/16 (31\%) among the patients not subjected to HSCT. 5 -year overall survival rates after auto-HSCT and allo-HSCT were $87 \%$ and $77 \%$, respectively. The results show that implementation of novel therapeutic agents, as well as consolidation with high-dose chemotherapy and auto- or allo-HSCT in selected cases improve outcomes in patients with $\mathrm{r} / \mathrm{r}$ TCL. Brentuximab vedotin and nivolumab-based regimens may be successfully used as a bridge therapy before HSCT.

\section{Keywords}

T-cell lymphoma, autologous hematopoietic stem cells transplantation, allogeneic hematopoietic stem cells transplantation, brentuximab vedotin, nivolumab. 


\section{Introduction}

The T-cell/natural killer (NK) cell lymphomas are a heterogeneous group of generally aggressive neoplasms that constitute less than 10-15 percent of all non-Hodgkin lymphomas (NHLs) in adults $[1,2]$. Modern classification of T/NK-cell lymphomas was developed on the basis of histological, immunohistochemical studies of tumor tissue and clinical presentation of lymphomas. In 2016, the World Health Organization classification revised the classification of both nodal and extranodal T/NK-cell lymphomas, which led to the introduction of new temporary structures [3]. Many of these changes were caused by the results of genomic studies using approaches to study gene expression profiling (GEP) and the genetic landscape of T/NK cell lymphomas. However, despite advances in molecular diagnostic methods, histological examination of tumor tissue and clinical manifestations remain the main diagnostic approach.

Another area of research concerns dismal outcomes in the patients with $\mathrm{T} / \mathrm{NK}$-cell lymphomas, except for anaplastic largecell lymphoma (ALCL) positive for anaplastic lymphoma kinase (ALK) [4]. There are currently no successful treatment standards for the T/NK-cell lymphomas, both in the first-line therapy, and in refractory/relapsed $(\mathrm{r} / \mathrm{r})$ settings. Today, almost $70 \%$ of patients undergoing first-line therapy develop a relapse or refractory disease. A review of the scientific literature allowed us to identify a range of therapeutic options for patients with T/NK-cell lymphomas [5]. It includes the following approaches:

- Hematopoietic stem cells transplantation (HSCT);

- Therapy with monoclonal antibodies (Mabs), e.g., anti-CD30 antibody-drug conjugate (Brentuximab vedotin), anti-CC chemokine receptor 4 antibodies (Mogamulizumab), a monoclonal antibody that binds to CD52 (Alemtuzumab), the monoclonal anti-vascular endothelial growth factor (Bevacizumab) [6-19];

- ALK inhibitors (Crizotinib, Ceritinib) [20];

- Therapy with immune checkpoint inhibitors, e.g., Nivolumab, Pembrolizumab, Ipilimumab, Durvalumab [21-27];

- Histone deacetylase inhibitors (Belinostat, Panobinostat, Chidamide, Romidepsin, Vorinostat) [28-34];

- CAR-T/NK-cell therapy $[35,36]$;

- In situ vaccination [37].

There are a lot of studies and a large number of drugs being introduced into clinical studies, but at the present time, greatest evidence base should be recognized for brentuximab and bone marrow transplantation. E.g., patients with $r / r$ T/NK-cell lymphomas who received hematopoietic stem cell transplantation (allogeneic and/or autologous) had a better outcome compared to the subset of non-transplanted patients (3-year survival rates of $48 \%$ and $18 \%$, respectively) [5]. These conclusions also supported by data of Abekasis et al., demonstrating that autologous and/or allogeneic HSCT is an effective and safe option for the consolidation of patients with TCL [38].

Recently published results of a clinical study ECHELON-2 showed that front-line treatment with Adcetris (brentuxi- mab vedotin) + CHP protocol is superior to CHOP for patients with CD30-positive peripheral T-cell lymphomas, thus suggesting that $\mathrm{A}+\mathrm{CHP}$ is likely to be the standard first-line therapy [39].

Also, brentuximab vedotin showed good results in the treatment of r/r CD30 positive TCL [40]. Mostly, there were anaplastic large cell lymphoma (ALCL), angioimmunoblastic T-cell lymphoma (AITL), Sézary syndrome and Mycosis Fungoides (MF) [7]. The objective response was from $92 \%$ to $40 \%$, with best results obtained in ALCL treatment $[41,42]$. These methods are actively used at our center.

Hence, the aim of this study was to present our single-center experience in the treatment of patients with T/NK-cell lymphomas.

\section{Patients and methods}

We analyzed data of 47 patients with TCL eligible for stem cells transplantation treated in the R. Gorbacheva Memorial Research Institute of Pediatric Oncology, Hematology and Transplantation at the Pavlov University from 2005 to 2019 including 44 cases with r/r TCL and 3 patients being in complete response after first-line therapy. Among them, 10 patients were diagnosed with anaplastic large cell lymphoma $(\mathrm{ALK}+) ; 5$ cases with anaplastic large cell lymphoma (ALK); 4 cases with angioimmunoblastic TCL (AITL); 4 patients with hepatosplenic T-cell lymphoma (HSTCL); 1 case of $\gamma \delta$ T cell lymphoma ( $\gamma \delta$ TCL); 20 patients with peripheral T-cell lymphoma not otherwise specified (PTCL-NOS); 1 patient with mucosis fungoides (MF); 1 , with primary cutaneous CD4+ T-cell lymphoma (CD4+ PCSM-TCL), and one patient with subcutaneous panniculitis-like T-cell lymphoma (SPTCL), as seen from Fig. 1.

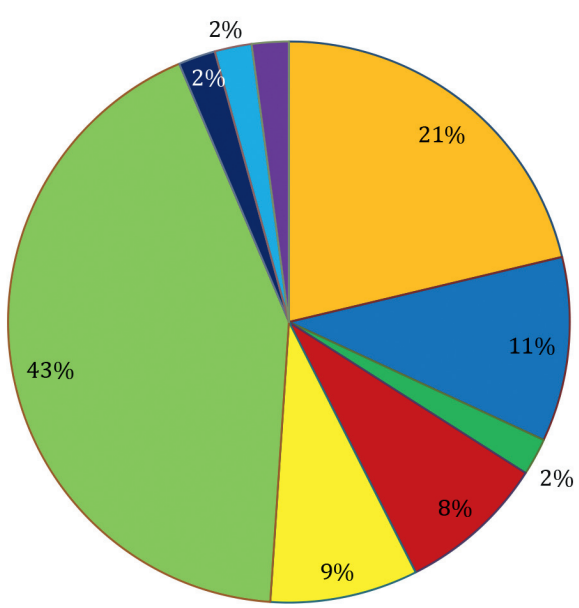
$\square \mathrm{ALK}+$
AITL
- $\mathrm{MF}$
$\square$ ALK-
$\square$ HSTCL
$\square$ SPTCL
$\square \gamma \delta$ TCL
$\square$ PTCL, NOS
- CD4+ PCSM-TLPD
Figure 1. Histological subtypes of patients with T-cell lymphomas treated at the R. Gorbacheva Memorial Institute 
Table 1. Clinical characteristics of T-cell lymphoma patients

\begin{tabular}{|l|l|}
\hline Characteristics & Patients \\
\hline Total patients, N & 47 \\
\hline Patients with CR after first line at that moment, N & 3 \\
\hline Patients with primary R/R disease, N (\%) & $26 / 18(55 / 38)$ \\
\hline Median age, years (range) & $45(1-72)$ \\
\hline Sex male/female, N (\%) & $29 / 18(62 / 38)$ \\
\hline $\begin{array}{l}\text { Median time from initial diagnosis to relapse or progression after primary } \\
\text { therapy, months (range) }\end{array}$ & $6.25(1-97)$ \\
\hline
\end{tabular}

General characteristics of the patients are outlined in Table 1.

The treatment was tailored according to biological tumor markers revealed in the patients. In 10 patients with CD30+ PTCL ( $n=4$ with PTCL-NOS; $n=4$ with ALK+; $n=1$ with ALK; $n=1$ with AITL), Brentuximab vedotin was used. One patient with ALK+ anaplastic lymphoma received ALK inhibitor crizotinib. Five patients with PD-L1 hyperexpression ( $n=4$ with PTCL-NOS; $n=1$ with $\gamma \delta$ TCL) were treated with nivolumab. Overall 24 patients underwent HSCT: highdose chemotherapy with auto-HSCT was performed in 16 patients, 13 patients underwent allo-HSCT (among them 5 patients with relapses after auto-HSCT). Place of auto-HSCT in the treatment of TCL in our center could be seen from Table 2 .

Main characteristics of patients who underwent allogeneic hematopoietic stem cells transplantation are shown in Table 3.
Table 2. Clinical state of the patients with T-cell lymphoma subjected to auto-HSCT

\begin{tabular}{|l|l|}
\hline Auto-HSCT & $\mathbf{n = 1 6}$ \\
\hline CR1 & 2 \\
\hline Chemosensitive relapse, CR2 & 10 \\
\hline Chemosensitive relapse, >CR2 & 4 \\
\hline
\end{tabular}

Table 3. Main clinical characteristics of 13 patients with $r / r$ TCL subjected to allo-HSCT

\begin{tabular}{|c|c|c|}
\hline Parameter & $\mathrm{n}=13$ & $\%$ \\
\hline Age at transplantation, years (range) & $45(18-57)$ & - \\
\hline Sex: male/female, years & $9 / 6$ & - \\
\hline $\begin{array}{l}\text { Ann Arbor staging at diagnosis: } \\
\text { - III } \\
\text { - IV }\end{array}$ & $\begin{array}{c}3 \\
10\end{array}$ & $\begin{array}{l}23 \% \\
77 \%\end{array}$ \\
\hline B-symptoms & 10 & $77 \%$ \\
\hline Median number of lines of therapy before allo-HSCT, N (range) & $4(1-4)$ & - \\
\hline Auto-HSCT before allo-HSCT, N & 5 & - \\
\hline Median observation before allo-HSCT, months (range) & $21(5-55)$ & - \\
\hline $\begin{array}{l}\text { Status at allo-HSCT: } \\
\text { - Complete response } \\
\text { - Partial response } \\
\text { - Stabilization of disease } \\
\text { - Progressive disease }\end{array}$ & $\begin{array}{l}7 \\
3 \\
1 \\
2\end{array}$ & $\begin{array}{c}54 \% \\
23.5 \% \\
7.5 \% \\
15 \%\end{array}$ \\
\hline
\end{tabular}




\section{Statistical analysis}

Data analysis was performed using SPSS software. The descriptive statistics methods were applied when appropriate. Both OS and PFS were censored at the date of the last contact and were estimated using the Kaplan-Meier method. The difference in OS was tested with log-rank test.

\section{Results}

At the time of analysis, 35 patients remained alive. These were mainly patients with peripheral T-cell lymphoma not otherwise specified (TCL-NOS), and anaplastic large cell lymphoma (LCL), ALK+ as the most common histological subtype and the histological subtype with the best prognosis, respectively (Fig. 2).

Results of treatment of patients of our center are presented in the Table 4.

The median follow-up of alive patients was 35 months (6-122 mo). The median overall survival was not reached, 5 -year survival rate was $81 \%$ and 8 -year survival rate was $78 \%$ (Fig. 3 and 4).

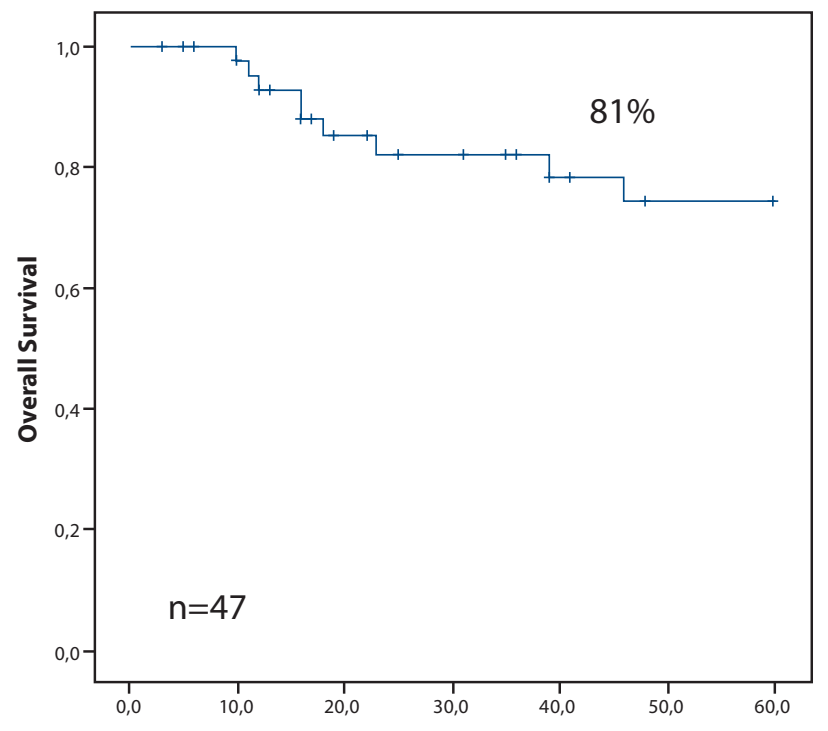

A

Months

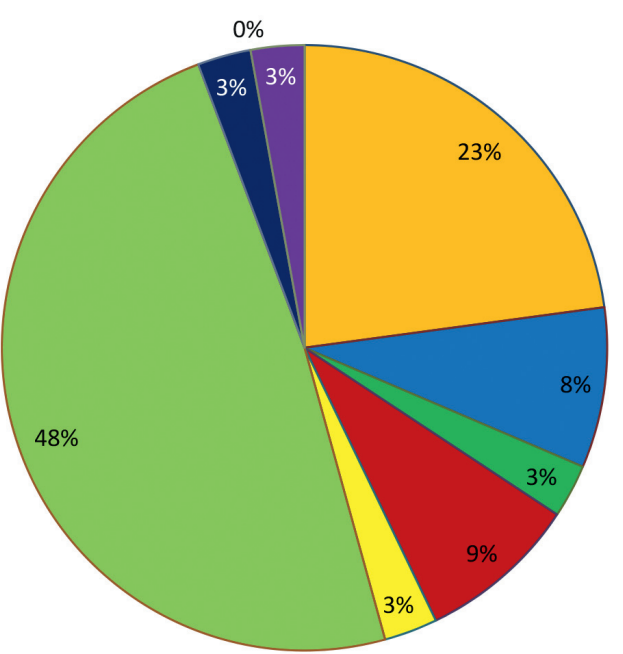

$\square$ ALK+

AITL

- MF

$\square$ ALK-

$\square \mathrm{HSTCL}$

$\square$ SPTCL

$\square \gamma \delta \mathrm{TCL}$

$\square$ PTCL, NOS

CD4+ PCSM-TLPD

Figure 2. Histological subtypes of the TCL patients remain alive. For abbreviations, see Materials and Methods

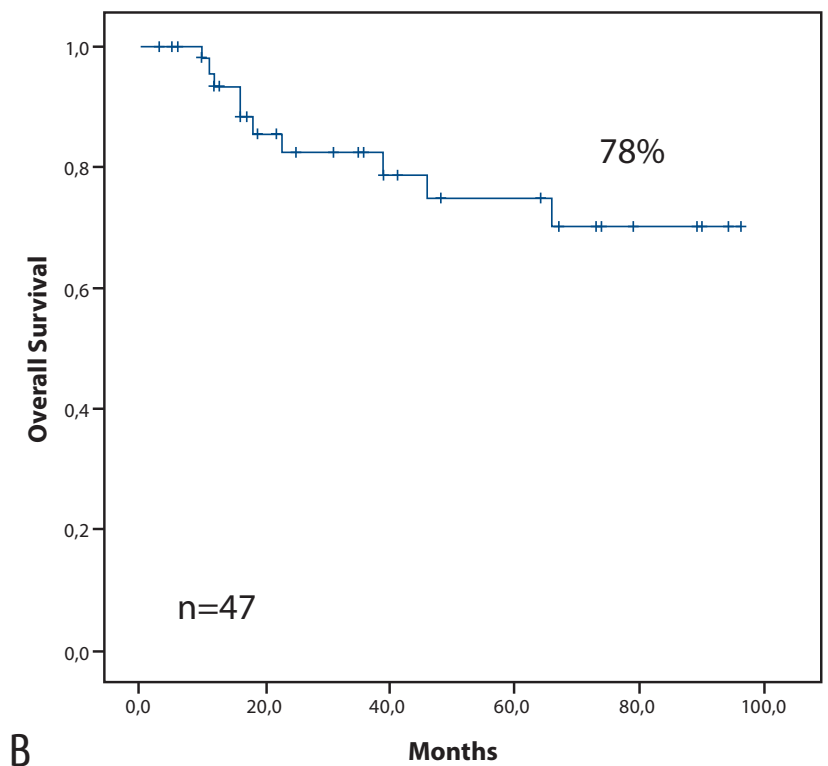

Figure 3, 4. 5-year (A) and 8-year (B) overall survival patients with T-cell lymphoma treated at R. Gorbacheva Memorial Institute

Table 4. Clinical state and survival rates of the TCL patients after HSCT

\begin{tabular}{|l|l|l|l|l|l|l|l|l|}
\hline & N=47 & CR & PR & PD/RD & $\begin{array}{l}\text { Duration of response } \\
\text { to RD after HSCT } \\
\text { (months) }\end{array}$ & 0S, \% & PFS, \% & $\begin{array}{l}\text { Current } \\
\text { status } \\
\text { (alive/dead) }\end{array}$ \\
\hline $\begin{array}{l}\text { Allo-HSCT (with 5 patients } \\
\text { after auto-HSCT) }\end{array}$ & 13 & 9 & 0 & $2 / 2$ & 4 and 7 months & $\begin{array}{l}77 \text { (5-year } \\
\text { survival) }\end{array}$ & $\begin{array}{l}61 \text { (5-year } \\
\text { survival) }\end{array}$ & $10 / 3$ \\
\hline Auto-HSCT & 16 & 8 & 0 & $1 / 7$ & Median 8 (1-30) & $\begin{array}{l}87 \text { (5-year } \\
\text { survival) }\end{array}$ & $\begin{array}{l}50 \text { (5-year } \\
\text { survival) }\end{array}$ & $14 / 2$ \\
\hline Without HSCT & $23^{*}$ & 5 & 4 & $12 / 2$ & - & $\begin{array}{l}74 \text { (8-year } \\
\text { survival) }\end{array}$ & $\begin{array}{l}\text { 13 (8-year } \\
\text { survival) }\end{array}$ & $16 / 7$ \\
\hline
\end{tabular}



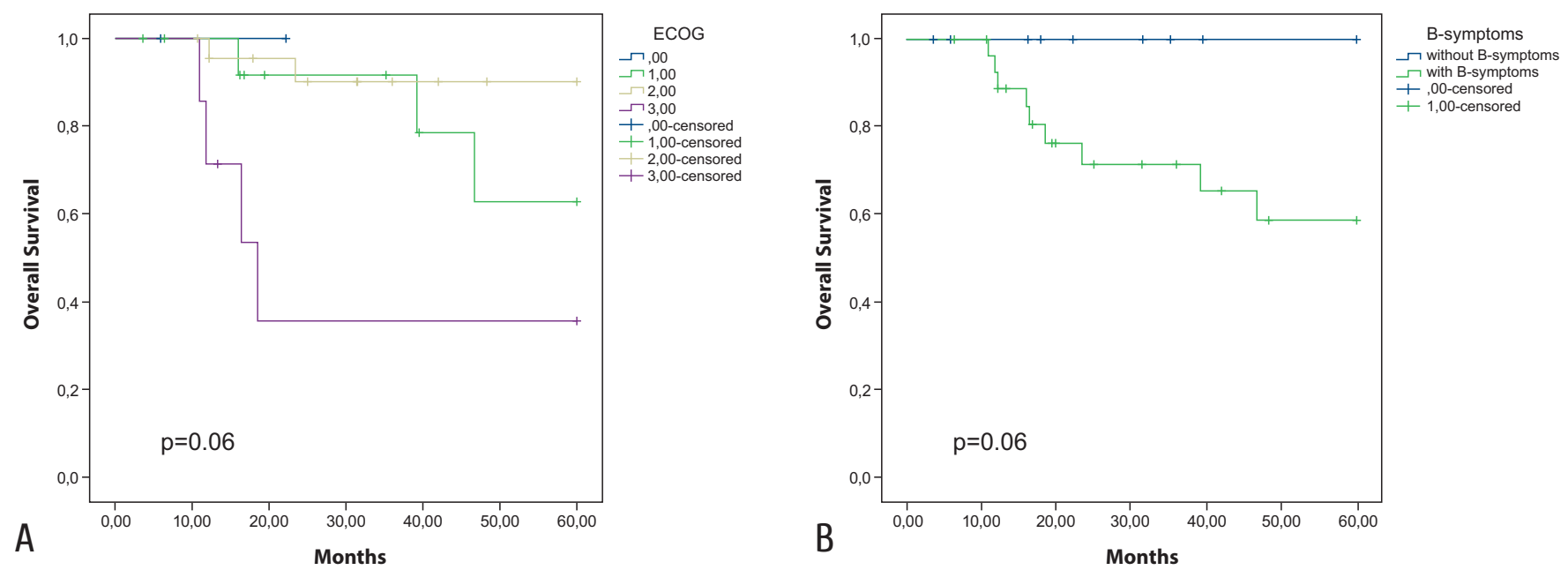

Figure 5, 6. 5-year survival rates depend on ECOG performance status (A), and presence of B-symptoms (B). The difference is significant by $\mathrm{p}=0.06$

Complete remission (CR) state was maintained at the last follow up in 22 patients, partial remission (PR) was documented in 4 patients and PD, in 21 case. Among factors significantly associated with adverse prognosis were: lower ECOG performance status and B-symptoms at the time of diagnosis (p=0.06) (Fig. 5 and 6).

Patients that had undergo HSCT showed significantly better disease status at the moment of last follow up: 17/19 (89\%) were in CR, versus 5/16 (31\%) in patients who did not undergo HSCT (Fig. 7). This can probably be attributed to the fact that patients had a good disease status before transplantation. I would also like to note that such a large number of patients who have not undergone HSCT is associated with age and severe comorbid status, the absence of a donor, unsuccessful apheresis of hematopoietic stem cell, or patient refusal from HSCT.

3-year progression-free survival in patients with TCL after auto-HSCT and allo-HSCT was 50\%. And 61\%, respectively (Fig. 8, 9).

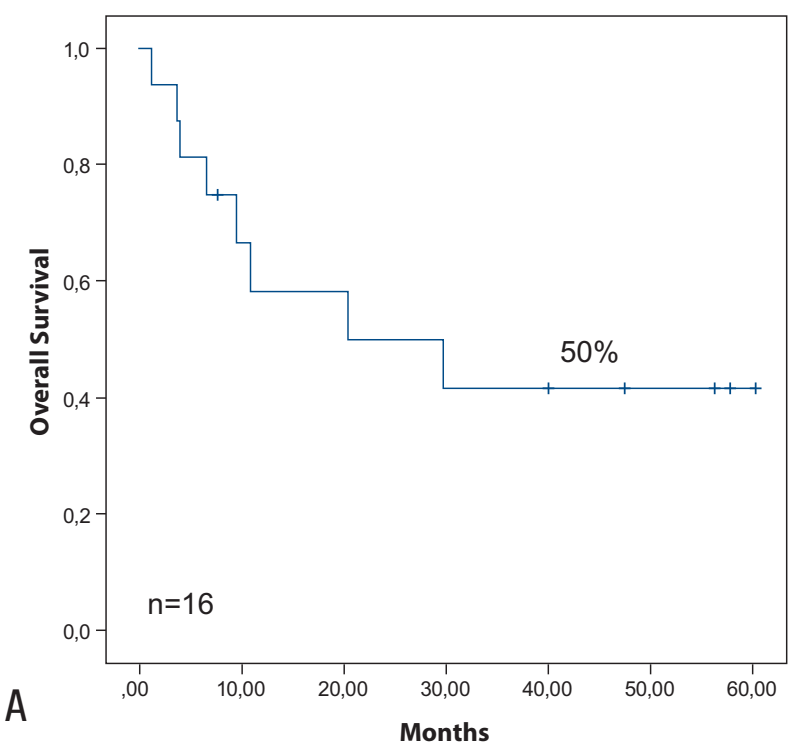

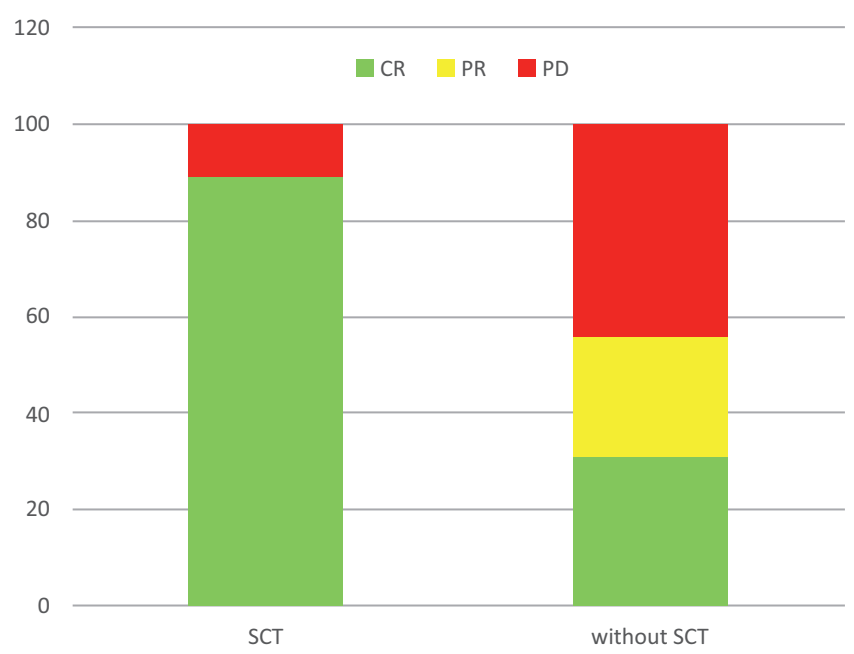

Figure 7. Disease status for patients remain alive

Figure 8, 9. 5-year progression-free survival for patients with T-cell lymphoma after autoHSCT (A) and allogeneic HSCT (B) 

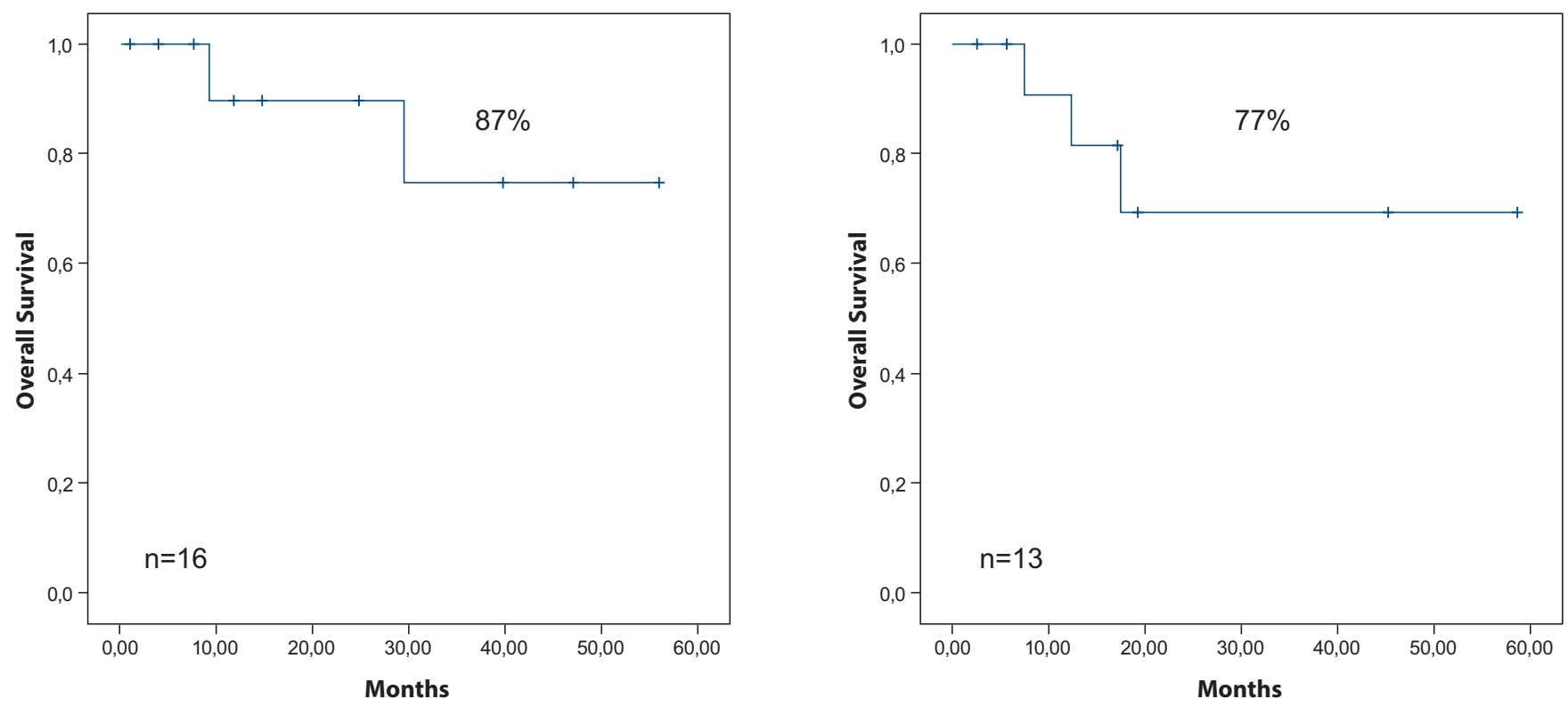

Figure 10, 11. 5-year overall survival for patients with T-cell lymphoma after auto-HSCT (A) and allo-HSCT (B)

5-year overall survival after auto-HSCT and allo-HSCT rate was $87 \%$ and $77 \%$ respectively (Fig. 10 and 11 ).

\section{Discussion}

Today there is no generally adopted strategy for achievement of responses for $\mathrm{r} / \mathrm{r}$ patients with PTCL and CTCL (cutaneous TCL), and significant improvements are needed in treatment methods for all subtypes of T/NK-cell lymphomas.

One such solution may be in the future, that we can expect combination therapies of new agents with cytotoxic chemotherapies, therapeutic combinations consisting of new agents and the use of these combinations in earlier in the course of treatment - addition to the first line of therapy. This statement is generally confirmed by the successful experience of our center, which consists in the use of some new drugs, taking into account biological tumor markers.

Our study also shows that HSCT improves the results, which is comparable with the data in world literature.

The consolidation auto-HSCT of achieved remission after first-line therapy can change overall survival for the better [5].

Allo-HSCT has the most solid evidence of the potential to significantly prolong survival or for the cure of disease [43]. But this method is not perfect due to a number of reasons: transplant-related mortality, absence of a donor for allo-HSCT, few appropriate candidates because of age, lack of adequate response to primary therapy, and/or absence of effective agents in the relapsed/refractory setting [44].

Nevertheless, over the past year, there has been a positive trend in allogeneic bone marrow transplantation, which is associated with the introduction of new conditioning regimens, prevention of graft-versus-host disease, new accompanying therapy.
These methods are used at our institute, but it should be noted that not only the improvement of approaches to the treatment of patients with TCL led to good results, but also the artificial selection of patients. Historically, we have accommodated patients who could theoretically become candidates for HSCT, which means patients with good comorbid status.

For the patients who are not candidates for hematopoietic stem cell transplantation the novel therapies (CAR-T/NKcell therapy; monoclonal antibodies therapy, molecularly targeted therapy) may become the new successful standard of treatment [45].

\section{Conclusion}

Our results show that introduction of novel agents and consolidation with high dose chemotherapy and auto-HSCT or allo-HSCT in selected cases improve outcomes in patients with $\mathrm{r} / \mathrm{r}$ TCL. Brentuximab vedotin and nivolumab based treatment may be successfully used as a bridge therapy before HSCT. The treatment was tailored according to hyperexpression CD30 and PD-L1.

\section{Conflict of interest}

The authors report no conflicts of interest.

\section{References}

1. WHO Classification of Tumours of Haematopoietic and Lymphoid Tissues. 4th ed. Lyon, France: IARC Press; 2008.

2. Mikhailova NB, Morozova EV, Leenman EE, Afanasyev BV. Subcutaneous panniculitis-like T-cell lymphoma. Case report and literature review. Clinical Oncohematology. 2008; 1(4):356-360 (In Russian). 
3. Swerdlow SH, Campo E, Pileri SA, Harris NL, Stein H, Siebert R, Advani R, Ghielmini M, Salles GA, Zelenetz AD, Jaffe ES. The 2016 revision of the World Health Organization classification of lymphoid neoplasms. Blood. 2016;127(20):2375-2390.

4. Vose J, Armitage J, Weisenburger D. International T-Cell Lymphoma Project. International peripheral T-cell and natural killer/T-cell lymphoma study: pathology findings and clinical outcomes. J Clin Oncol. 2008;26(25):4124-4130.

5. Bellei M, Foss FM, Shustov AR, Horwitz SM, Marcheselli L, Kim WS, Cabrera ME, Dlouhy I, Nagler A, Advani RH, Pesce EA, Ko Y-H, Martinez V, Montoto Silvia, Chiattone C, Moskowitz A, Spina M, Biasoli I, Manni M, Federico M, International T-cell Project Network. The outcome of peripheral T-cell lymphoma patients failing first-line therapy: a report from the prospective, International T-Cell Project. Haematologica. 2018;103(7):1191-1197.

6. Ishida T, Joh T, Uike N, Yamamoto K, Utsunomiya A, Yoshida S, Saburi Y, Miyamoto T, Takemoto S, Suzushima H, Tsukasaki K, Nosaka K, Fujiwara H, Ishitsuka K, Inagaki H, Ogura M, Akinaga S, Tomonaga M, Tobinai K, Ueda R. Defucosylated anti-CCR4 monoclonal antibody (KW-0761) for relapsed adult T-cell leukemia-lymphoma: a multicenter phase II study. J Clin Oncol. 2012;30(8):837-842.

7. Phillips AA, Fields PA, Hermine O, Ramos JC, Beltran BE, Pereira J, Wandroo F, Feldman T, Taylor GP, Sawas A, Humphrey J, Kurman M, Moriya J, Dwyer K, Leoni M, Conlon K, Cook L, Gonsky J, Horwitz SM, 0761-009 Study Group. Mogamulizumab versus investigator's choice of chemotherapy regimen in relapsed/refractory adult T-cell leukemia/ lymphoma. Haematologica. 2019;104(5):993-1003.

8. Duvic M, Pinter-Brown LC, Foss FM, Sokol L, Jorgensen JL, Challagundla P, Dwyer KM, Zhang X, Kurman MR, Ballerini R, Liu L, Kim YH. Phase 1/2 study of mogamulizumab, a defucosylated anti-CCR4 antibody, in previously treated patients with cutaneous T-cell lymphoma. Blood. 2015;125(12):1883-1889.

9. Ogura M, Ishida T, Hatake K, Taniwaki M, Ando K, Tobinai K, Fujimoto K, Yamamoto K, Miyamoto T, Uike N, Tanimoto M, Tsukasaki K, Ishizawa K, Suzumiya J, Inagaki H, Tamura K, Akinaga S, Tomonaga M, Ueda R. Multicenter phase II study of mogamulizumab (KW-0761), a defucosylated anti-cc chemokine receptor 4 antibody, in patients with relapsed peripheral T-cell lymphoma and cutaneous T-cell lymphoma. J Clin Oncol. 2014;32(11):1157-1163.

10. Kim YH, Bagot M, Pinter-Brown L, Rook AH, Porcu P, Horwitz SM, Whittaker S, Tokura Y, Vermeer M, Zinzani PL, Sokol L, Morris S, Kim EJ, Ortiz-Romero PL, Eradat H, et al. Mogamulizumab versus vorinostat in previously treated cutaneous T-cell lymphoma (MAVORIC): an international, open-label, randomised, controlled phase 3 trial. Lancet Oncol. 2018;19(9):1192-1204.

11. Lundin J, Hagberg H, Repp R, Cavallin-Ståhl E, Fredén S, Juliusson G, Rosenblad E, Tjønnfjord G, Wiklund T, Osterborg A. Phase 2 study of alemtuzumab (anti-CD52 monoclonal antibody) in patients with advanced mycosis fungoides/ Sezary syndrome. Blood. 2003;101(11):4267-4272.
12. Enblad G, Hagberg H, Erlanson M, Lundin J, MacDonald AP, Repp R, Schetelig J, Seipelt G, Osterborg A. A pilot study of alemtuzumab (anti-CD52 monoclonal antibody) therapy for patients with relapsed or chemotherapy-refractory peripheral T-cell lymphomas. Blood. 2004;103(8):2920-2924.

13. de Masson A, Guitera P, Brice P, Moulonguet I, Mouly F, Bouaziz JD, Battistella M, Madelaine I, Roux J, Ram-Wolff C, Cayuela JM, Bachelez H, Bensussan A, Michel L, Bagot M. Long-term efficacy and safety of alemtuzumab in advanced primary cutaneous T-cell lymphomas. Br J Dermatol. 2014; 170(3):720-724.

14. Zinzani PL, Alinari L, Tani M, Fina M, Pileri S, Baccarani M. Preliminary observations of a phase II study of reduced-dose alemtuzumab treatment in patients with pretreated T-cell lymphoma. Haematologica. 2005;90(5):702-703.

15. Kim SJ, Kim K, Park Y, Kim BS, Huh J, Ko YH, Park K, Suh C, Kim WS. Dose modification of alemtuzumab in combination with dexamethasone, cytarabine, and cisplatin in patients with relapsed or refractory peripheral T-cell lymphoma: analysis of efficacy and toxicity. Invest New Drugs. 2012;30(1):368-375.

16. Kim JG, Sohn SK, Chae YS, Cho YY, Yang DH, Lee JJ, Kim HJ, Shin HJ, Chung JS, Cho GJ, Lee WS, Joo YD, Sohn CH, Oh SJ. Alemtuzumab plus CHOP as front-line chemotherapy for patients with peripheral T-cell lymphomas: a phase II study. Cancer Chemother Pharmacol. 2007;60(1):129-134.

17. Gallamini A, Zaja F, Patti C, Billio A, Specchia MR, Tucci A, Levis A, Manna A, Secondo V, Rigacci L, Pinto A, Iannitto E, Zoli V, Torchio P, Pileri S, Tarella C. Alemtuzumab (Campath-1H) and CHOP chemotherapy as first-line treatment of peripheral T-cell lymphoma: results of a GITIL (Gruppo Italiano Terapie Innovative nei Linfomi) prospective multicenter trial. Blood. 2007;110(7):2316-2323.

18. Kluin-Nelemans HC, van Marwijk Kooy M, Lugtenburg PJ, van Putten WL, Luten M, Oudejans J, van Imhoff GW. Intensified alemtuzumab-CHOP therapy for peripheral T-cell lymphoma. Ann Oncol. 2011;22(7):1595-600.

19. Ganjoo K, Hong F, Horning SJ, Gascoyne RD, Natkunam Y, Swinnen LJ, Habermann TM, Kahl BS, Advani RH. Bevacizumab and cyclosphosphamide, doxorubicin, vincristine and prednisone in combination for patients with peripheral T-cell or natural killer cell neoplasms: an Eastern Cooperative Oncology Group study (E2404). Leuk Lymphoma. 2014;55(4):768-772.

20. Hapgood G, Savage KJ. The biology and management of systemic anaplastic large cell lymphoma. Blood. 2015;126(1):17-25.

21. Lesokhin AM, Ansell SM, Armand P, Scott EC, Halwani A, Gutierrez M, Millenson MM, Cohen AD, Schuster SJ, Lebovic D, Dhodapkar M, Avigan D, Chapuy B, Ligon AH, Freeman GJ, Rodig SJ, Cattry D, Zhu L, Grosso JF, Bradley Garelik MB, Shipp MA, Borrello I, Timmerman J. Nivolum$\mathrm{ab}$ in patients with relapsed or refractory hematologic malignancy: preliminary results of a phase Ib study. J Clin Oncol. 2016;34(23):2698-2704. 
22. Khodadoust M, Rook AH, Porcu P, Foss FM, Moskowitz AJ, Shustov AR, Shanbhag S, Sokol L, Shine R, Fling S, Li S, Rabhar Z, Kim J, Yang Y, Yearley J et al. Pembrolizum$\mathrm{ab}$ for treatment of relapsed/refractory mycosis fungoides and Sezary syndrome: clinical efficacy in a Citn multicenter phase 2 study. Blood. 2016; 128 (22): 181.

23. Kwong YL, Chan TSY, Tan D, Kim SJ, Poon LM, Mow B, Khong PL, Loong F, Au-Yeung R, Iqbal J, Phipps C, Tse E. PD1 blockade with pembrolizumab is highly effective in relapsed or refractory NK/T-cell lymphoma failing l-asparaginase. Blood. 2017 Apr 27;129(17):2437-2442.

24. Barta SK, Zain J, MacFarlane AW 4th, Smith SM, Ruan J, Fung HC, Tan CR, Yang Y, Alpaugh RK, Dulaimi E, Ross EA, Campbell KS, Khan N, Siddharta R, Fowler NH, Fisher RI, Oki Y. Phase II study of the PD-1 inhibitor pembrolizumab for the treatment of relapsed or refractory mature T-cell lymphoma. Clin Lymphoma Myeloma Leuk. 2019;19(6):356364.e3.

25. Rong Tao, Lei Fan, Yongping Song, Yu Hu, Wei Zhang, Yafei Wang, Linxinyu Xu, Hui Zhou, Jianyong Li. Sintilimab for relapsed/refractory (r/r) extranodal NK/T-cell lymphoma (ENKTL): A multicenter, single-arm, phase 2 trial (ORIENT-4). J Clin Oncol. 2019; 37(15 Suppl): 7504-7504.

26. Ansell S, Gutierrez ME, Shipp MA, Gladstone DE, Moskowitz AJ, Borello I, Popa-Mckiver M, Farsaci B, Zhu L, Lesokhin AM, Armand P. A phase 1 study of nivolumab in combination with ipilimumab for relapsed or refractory hematologic malignancies (CheckMate 039). Blood (2016) 128 (22): 183. doi.org/10.1182/blood.V128.22.183.183.

27. Querfeld C, Zain JM, Wakefield DL, Jovanovic-Talisman T, Kil SH, Estephan R, Sanchez J, Palmer J, Rosen ST. Phase $1 / 2$ trial of durvalumab and lenalidomide in patients with cutaneous $\mathrm{T}$ cell lymphoma (CTCL): preliminary results of Phase I results and correlative studies. Blood 2018; 132 (Supplement 1): 2931. doi: https://doi.org/10.1182/ blood-2018-99-114001.

28. Eyal S, Yagen B, Shimshoni J, Bialer M. Histone deacetylases inhibition and tumor cells cytotoxicity by CNS-active VPA constitutional isomers and derivatives. Biochem Pharmacol. 2005;69(10):1501-1508.

29. O'Connor OA, Horwitz S, Masszi T, Van Hoof A, Brown P, Doorduijn J, Hess G, Jurczak W, Knoblauch P, Chawla S, Bhat G, Choi MR, Walewski J, Savage K, Foss F, Allen LF, Shustov A. Belinostat in patients with relapsed or refractory peripheral T-cell lymphoma: results of the pivotal phase II BELIEF (CLN-19) Study. J Clin Oncol. 2015;33(23):24922499.

30. Duvic M, Dummer R, Becker JC, Poulalhon N, Ortiz Romero P, Grazia Bernengo M, Lebbé C, Assaf C, Squier M, Williams D, Marshood M, Tai F, Prince HM. Panobinostat activity in both bexarotene-exposed and -naïve patients with refractory cutaneous T-cell lymphoma: results of a phase II trial. Eur J Cancer. 2013:49(2):386-394.

31. Shi Y, Dong M, Hong X, Zhang W, Feng J, Zhu J, Yu L, Ke X, Huang H, Shen Z, Fan Y, Li W, Zhao X, Qi J, Huang H, Zhou D, Ning Z, Lu X. Results from a multicenter, open-label, pivotal phase II study of chidamide in relapsed or refractory peripheral T-cell lymphoma. Ann Oncol. 2015;26(8):17661771.

32. Coiffier B, Pro B, Prince HM, Foss F, Sokol L, Greenwood M, Caballero D, Borchmann P, Morschhauser F, Wilhelm M, Pinter-Brown L, Padmanabhan S, Shustov A, Nichols J, Carroll S, Balser J, Balser B, Horwitz S. Results from a pivotal, open-label, phase II study of romidepsin in relapsed or refractory peripheral T-cell lymphoma after prior systemic therapy. J Clin Oncol. 2012;30(6):631-636.

33. Duvic M, Talpur R, Ni X, Zhang C, Hazarika P, Kelly C, Chiao JH, Reilly JF, Ricker JL, Richon VM, Frankel SR. Phase 2 trial of oral vorinostat (suberoylanilide hydroxamic acid, SAHA) for refractory cutaneous T-cell lymphoma (CTCL). Blood. 2007;109(1):31-39.

34. Kim SJ, Kim JH, Ki CS, Ko YH, Kim JS, Kim WS. Epstein-Barr virus reactivation in extranodal natural killer/Tcell lymphoma patients: a previously unrecognized serious adverse event in a pilot study with romidepsin. Ann Oncol. 2016;27(3):508-513.

35. Poggio T, Duyster J, Illert AL. Current immunotherapeutic approaches in T cell non-Hodgkin lymphomas. Cancers (Basel). 2018;10(9):339. 2018 Sep 18. doi:10.3390/cancers10090339.

36. Scarfò I, Frigault MJ, Maus MV. CAR-based approaches to cutaneous T-cell lymphoma. Front Oncol. 2019;9:259. doi:10.3389/fonc.2019.00259.

37. Kim YH, Gratzinger D, Harrison C, Brody JD, Czerwinski DK, Ai WZ, Morales A, Abdulla F, Xing L, Navi D, Tibshirani RJ, Advani RH, Lingala B, Shah S, Hoppe RT, Levy R. In situ vaccination against mycosis fungoides by intratumoral injection of a TLR9 agonist combined with radiation: a phase 1/2 study. Blood. 2012;119(2):355-363.

38. Abecasis M, Gomez C, Ferreira I, Gomes da Silva M, Miranda N, Teixeira G, Leal da Costa F, João Gutierrez M. Stem cell transplantation as consolidation in peripheral T-cell lymphomas. Cell Ther Transplant 2020; 9(1): 22-27.

39. Horwitz S, O'Connor OA, Pro B, Illidge T, Fanale M, Advani R, Bartlett NL, Christensen JH, Morschhauser F, Domingo-Domenech E, Rossi G, Kim WS, Feldman T, Lennard A, Belada D, Illés A. Brentuximab vedotin with chemotherapy for CD30-positive peripheral T-cell lymphoma (ECHELON-2): a global, double-blind, randomised, phase 3 trial. Lancet. 2019;393(10168):229-240.

40. Pro B, Advani R, Brice P, Bartlett NL, Rosenblatt JD, Illidge T, Matous J, Ramchandren R, Fanale M, Connors JM, Fenton K, Huebner D, Pinelli JM, Kennedy DA, Shustov A. Five-year results of brentuximab vedotin in patients with relapsed or refractory systemic anaplastic large cell lymphoma. Blood. 2017;130(25):2709-2717.

41. Kim YH, Tavallaee M, Sundram U, Salva KA, Wood GS, Li S, Rozati S, Nagpal S, Krathen M, Reddy S, Hoppe RT, Nguyen-Lin A, Weng WK, Armstrong R, Pulitzer M, Advani $\mathrm{RH}$, Horwitz SM. Phase II investigator-initiated study of Brentuximab Vedotin in mycosis fungoides and Sézary 
syndrome with variable CD30 expression level: a multi-institution collaborative project. J Clin Oncol. 2015;33(32):37503758.

42. Horwitz SM, Advani RH, Bartlett NL, Jacobsen ED, Sharman JP, O'Connor OA, Siddiqi T, Kennedy DA, OkI Y. Objective responses in relapsed T-cell lymphomas with single-agent brentuximab vedotin. Blood. 2014;123(20):30953100 .

43. Duarte RF, Labopin M, Bader P, Basak GW, Bonini C, Chabannon C, Corbacioglu S, Dreger P, Dufour C, Gennery AR, Kuball J, Lankester AC, Lanza F, Montoto S, Nagler A, Peffault de Latour R, Snowden JA, Styczynski J, Yakoub-Agha I, Kröger N, Mohty M; European Society for Blood and Marrow Transplantation (EBMT). Indications for haematopoietic stem cell transplantation for haematological diseases, solid tumours and immune disorders: current practice in Europe, 2019. Bone Marrow Transplant. 2019;54(10):1525-1552.

44. Trajkovska I, Georgievski B, Cevreska L, Gacovski A, Hasan T, Nedeska-Minova N. Early and late complications in patients with allogeneic transplantation of hematopoietic stem cell - case report. Open Access Maced J Med Sci. 2017;5(3):340-343. Publ. 2017 May 9. doi:10.3889/oamjms. 2017.038

45. Marchi E, O'Connor OA. The rapidly changing landscape in mature T-cell lymphoma (MTCL) biology and management. CA A Cancer J Clin. 2020;70:47-70. 


\title{
Варианты лечения Т-клеточных лимфом: данные одноцентрового исследования
}

\author{
Елена Е. Лепик ${ }^{1}$, Андрей В. Козлов ${ }^{1}$, Евгения С. Борзенкова ${ }^{1}$, Юрий Р. Залялов ${ }^{1}$, Кирилл В. Лепик ${ }^{1}$, \\ Елена В. Кондакова ${ }^{1}$, Вадим В. Байков ${ }^{1}$, Иван С. Моисеев ${ }^{1}$, Татьяна В. Шнайдер ${ }^{2}$, Наталья Б. Михайлова ${ }^{1}$, \\ Борис В. Афанасьев ${ }^{1}$ \\ ${ }^{1}$ НИИ детской онкологии, гематологии и трансплантологии им. Р. М. Горбачевой, Первый Санкт-Петербургский \\ государственный медицинский университет им. акад. И. П. Павлова, Санкт-Петербург, Россия \\ 2 Ленинградская областная клиническая больница, Санкт-Петербург, Россия
}

\section{Резюме}

Т-клеточные лимфомы (ТКЛ) представляют собой агрессивные неходжкинские лимфомы, которые не имеют успешных стандартов лечения. Почти у $70 \%$ пациентов после первой линии терапии развивается рецидив или рефрактерное течение (p/p). Ряд новых терапевтических подходов нацелены на улучшение результатов лечения у пациентов с p/p ТКЛ. В данной статье обобщен опыт Первого СанктПетербургского государственного медицинского университета им. Павлова в лечении пациентов с Т-клеточными лимфомами. Мы проанализировали данные 47 пациентов, которые проходила лечение с 2005 по 2019 год - на момент анализа 44 пациента имеют $\mathrm{p} / \mathrm{p}$ течение заболевания и 3 пациента находятся в полном ответе после проведенной первой линии терапии. Средний возраст составил 45 лет (от 1 года до 72 лет). Это были преимущественно пациенты с периферическими Т-клеточными лимфомами, неуточненными (41\%). Среди всех пациентов n26 (55\%) имели первичное химиорезистентное течение, в то время как у остальных n18 (38\%) был рецидив после первой линии терапии.

Опыт нашего центра включает в себя использование новых вариантов лечения p/p ТКЛ: антиCD30 моноклональное антитело - брентуксимаб, ингибитор ALK - кризотиниб, ингибитор контрольных точек - ниволумаб и иммунотерапию, включающую проведение трансплантации гемопоэтических стволовых клеток (ТГСК). В общей сложности 24 пациентам выполнена ТГСК: высокодозная химиотерапия с последующей аутологичной ТГСК (аутоТГСК) проведена 16 пациентам, 13 пациентам - аллогенная ТГСК (алло-ТГСК) (из них 5 пациентов с рецидивами после ауто-ТГСК).
На момент анализа 35 пациентов были живы. Медиана наблюдения за живыми пациентами составила 35 месяцев (6-122 мес.). Медиана общей выживаемости не была достигнута, 5-летняя выживаемость составила $81 \%, 8$-летняя общая выживаемость - 78\%. Статус заболевания при последнем наблюдении был следующий: полный ответ у 22 пациентов, частичный ответ у 4 пациентов и прогрессия заболевания у 21. Среди факторов, значительно связанных с неблагоприятным прогнозом, были низкий статус ECOG и В-симптомы на момент постановки диагноза $(\mathrm{p}=0,06)$. Пациенты, которые перенесли ТГСК, имели лучший статус заболевания на момент последнего наблюдения: 17/19 (89\%) были в полном ответе, по сравнению с 5/16 (31\%) у пациентов, которым не проводилась ТГСК. 5-летняя общая выживаемость у пациентов с ТКЛ после ауто-ТГСК и алло-ТГСК составила $87 \%$ и $77 \%$ соответственно. Результаты анализа показывают, что введение новых агентов и консолидация с помощью высокодозной химиотерапии с последующей ауто-ТГСК или алло-ТГСК в отдельных случаях могут улучшить результаты у пациентов с рецидивирующей или рефрактерной Т-клеточной лимфомой. Схемы, основанные на применении брентуксимаба ведотина и ниволумаба, могут быть успешно использованы в качестве bridge-терапии перед алло-ТГСК.

\section{Ключевые слова}

Т-клеточные лимфомы, аутологичная трансплантация гемопоэтических стволовых клеток, аллогенная трансплантация гемопоэтических стволовых клеток, брентуксимаб ведотин, ниволумаб. 